\title{
Moss and Soil Substrates Interact with Moisture Level to Influence Germination by Three Wetland Tree Species
}

\author{
Alexander Staunch, Marie Redlecki, Jessica Wooten, Jonathan Sleeper, and Jonathan Titus \\ Department of Biology, Jewett Hall, SUNY-Fredonia, Fredonia, NY 14063, USA \\ Correspondence should be addressed to Jonathan Titus, titus@fredonia.edu
}

Received 24 April 2012; Accepted 15 May 2012

Academic Editors: M. Jullien and S. Satoh

Copyright () 2012 Alexander Staunch et al. This is an open access article distributed under the Creative Commons Attribution License, which permits unrestricted use, distribution, and reproduction in any medium, provided the original work is properly cited.

\begin{abstract}
To assess germination success in different microsites of a forested wetland environment, seeds of three common western New York wetland tree species, Acer $x$ freemanii, Fraxinus pennsylvanica, and Ulmus americana, were sown into flats in the greenhouse with three substrates (mosses Hypnum imponens or Thuidium delicatulum or bare soil) and three hydrological conditions (wet, moist, or dry) in a factorial design. For the three species both treatment regimes and the interaction were highly significant, except for Acer, in which the substrate regime was not significant. Fraxinus germination had the highest tolerance for wet conditions and lowest for dry conditions followed by Acer and then Ulmus. Significant interactions showed that the effect of hydrological regime on germination is influenced by substrate type. Moss decreased germination under drier conditions and increased germination under wet conditions by lifting the seeds away from the soil and creating drier conditions than on bare soil. It is also possible that interspecific competition for moisture played a role in decreasing germination under dry conditions. By influencing the regeneration niche for three major tree species of swamps in the northeastern United States, the bryophyte layer plays an important role in determining community composition.
\end{abstract}

\section{Introduction}

Seed germination and seedling establishment are influenced by microsite environmental conditions. Favorable microsites or "safe sites" for seed germination and seedling establishment protect seeds and seedlings from extremes of temperature, humidity, moisture, and sunlight and affect nutrient availability, soil physical characteristics, seed predation, and a host of other factors. Thus, favorable microsites provide conditions beneficial for germination and establishment and their availability determines recruitment, which has a great impact on community composition, diversity, and succession [1-3]. An important aspect of a microsite, especially in wetlands, is microtopographic relief. In wetlands microsites with slight differences in elevation (centimeters) may differ in flooding duration, moisture retention, and availability, substrate composition and a host of other factors $[4,5]$. Thus, minor differences in elevation in a swamp may have a powerful effect on germination and survival due to differences in inundation period and moisture availability.
Influencing differences in germination and survival elevation plays a role in tree seed germination and seedling survival and thereby influences species composition of the swamp forest [5]. That is, minor differences in elevation are different germination or regeneration niches $[1,6]$.

Bryophytes are a common substrate type on swamp microsites with strong effects on seed germination and seedling establishment. In general the presence of a bryophyte mat may positively [7-9] or negatively [10-16] affect seed germination and seedling survival. Seeds that get caught in a moss mat often remain too dry to germinate or are too far from the ground for the radicle to reach the soil surface and fail to establish [17-22]. Competition for water between the moss and the seedling is an important factor, especially in dry habitats $[14,23]$. However, the presence of a bryophyte mat can lower temperatures and thereby reduce water stress on seeds and seedlings, and moss can reduce the rate of soil moisture loss, due to reduced evaporation and runoff positively influencing seedling survival especially in water-limited situations $[10,24,25]$. The position of a seed 
in the bryophyte mat and the size of the seed will interact to influence germination $[3,13,19]$. Species with larger seeds seem to be less influenced by the moss layer than smallseeded species [14].

Bryophyte effects on germination and establishment are species specific for the bryophyte and the vascular plant $[4,14,20,26]$. For example, effects of bryophytes may be related to their turf structure with a thick moss cover affecting seed germination negatively and a thin moss cover promoting germination $[4,14,27]$. A moss mat may have a negative effect on germination and a positive effect on seedling survival $[4,15,28,29]$. The effect of bryophytes on germination and seedling survival may differ between years depending on weather conditions [11].

A greenhouse study was conducted to investigate the effects of two moss species and bare soil under three hydrological regimes on the germination of seeds of the three dominant trees species, Acer $x$ freemanii, Fraxinus pennsylvanica, and Ulmus americana, of western New York swamp forests. The three hydrological regimes represent elevation on microsites in a swamp and the substrates are the three substrates commonly found on microsites, that is, bare soil and the mosses Hypnum imponens and Thuidium delicatulum. These substrates may mediate the effect of inundation and moisture availability, which are controlled by elevation, on germination. The hypothesis is that substrate type and hydrological regime will affect the germination of the three tree species differently. This experiment would thereby clarify if minor elevational differences may be different regeneration niches for these three species.

\section{Methods}

The seeds of Acer x freemanii E. Murray (Freeman's maple), Fraxinus pennsylvanica Marsh. (green ash), and Ulmus americana L. (American elm) were used in this study. These species were used because they dominate the woody seedling, sapling, and canopy layers of Bonita Swamp and in many other swamps throughout western New York [5]. The seeds of these three species have epigeal germination. Most of the seeds of Acer and Ulmus germinate immediately after dispersal [30-32]. Fraxinus seed is reported to have dormancy mechanisms (e.g., $[33,34]$ ) most likely because it is autumn-dispersed. Dirr [32] reported that Fraxinus seed requires 60 days at $20^{\circ} \mathrm{C}$ followed by 120 days at $0^{\circ} \mathrm{C}-$ $5^{\circ} \mathrm{C}$ to break dormancy. However, we have found $>50 \%$ germination with seed that was stored for 3 months under cool dry conditions and then planted in moist soil in the greenhouse (Titus unpubl. data). A cold stratification or other stratification treatments may increase germination beyond 50\% [34]. In any case, the seeds of these species do not require freezing or scarification and are not major contributors to seed banks [35-38]. Acer $x$ freemanii is a hybrid between Acer rubrum and Acer saccharinum and is identified by leaf and samara characteristics that are intermediate between the parent species $[30,39,40]$. These are large fruited species. Acer seeds with their samaras measured $4.3-5.8 \mathrm{~cm}$ long by $1.3-1.9 \mathrm{~cm}$ wide. Ulmus seeds, in which the samara completely encircles the seed in an oval shape, were $1.0-1.3$ by $1.2-1.5 \mathrm{~cm}$ for the two diameters. Fraxinus seeds have a narrower samara than Acer and were $3.8-4.4 \mathrm{~cm}$ long by $0.7-0.9 \mathrm{~cm}$ wide.

These tree species were selected because of their prevalence in Bonita Swamp, which is located along the Chadakoin River near Jamestown, Chautauqua County, NY (N 420730, W 0791709, $393 \mathrm{~m}$ asl). The 20.64 ha Bonita Swamp was purchased in 2004 by Chautauqua Watershed Conservancy and is part of the Chautauqua Lake Outlet Wetland Preserve (Chautauqua Watershed Conservancy 2009). Bonita Swamp is a palustrine, forested, deciduous, seasonally flooded (USUI, USGS 1996) class I wetland (NYSDEC 2007). The vegetation and hydrology of Bonita swamp are outlined in Blood and Titus [5]. Bonita Swamp is microtopographically complex with small differences in elevation dictating the time an area is inundated, which has a strong influence on species regeneration. Two moss species, Hypnum imponens Hedw. and Thuidium delicatulum (Hedw.) Schimp. occur on raised microtopographic features and cover $30 \%$ of the swamp floor [5]. Bare soil, wood, and litter also occupy raised microsites. These mosses form dense mats about $2 \mathrm{~cm}$ thick in Bonita Swamp. Blood and Titus [5] showed that raised moss microsites in Bonita Swamp contain more seedlings than bare soil or woody substrates presumably because the seeds are lifted above the saturated or inundated substrate.

Seeds and moss were collected on the ground in Bonita Swamp from eight locations separated by more than $10 \mathrm{~m}$ from one another. The mosses (Hypnum and Thuidium) were collected on 31 March 2007 and cultivated on potting soil in the greenhouse. Acer seeds were collected 11 June 2009 and planted 3 July 2009. Fraxinus seeds were collected 22 September 2007 and planted 15 February 2008. Ulmus seeds were collected 6 June 2008 and planted 18 September 2008. Seeds were stored under cool dry conditions.

Identical greenhouse experiments were carried out in the SUNY Fredonia campus greenhouse in Fredonia, NY, on three separate occasions using the seeds of the three species described above. Germination experiments were conducted consecutively for each species and not simultaneously due to greenhouse space limitations.

For each species a total of $7226 \mathrm{~cm} \times 26 \mathrm{~cm}$ flats were prepared with 100 seeds planted in each flat for Fraxinus and Ulmus and 75 seeds for Acer. Two treatment regimes, hydrologic regime (wet, moist, dry) and substrate (Hypnum, Thuidium, bare soil) were applied in a factorial manner across the flats for a sample size of eight for each treatment combination. Hydrologic treatments were wet, moist, and dry conditions. Wet conditions were established by placing the flats into larger flats without drainage holes allowing the soil to be continuously saturated, and if moss was present, the moss was wet. Moist flats were watered every three or four days and the soil was never allowed to dry out; however, if moss was present, the surface of the moss would become dry. Dry flats were watered weekly and dried out between watering and the surface of the moss would be quite dry. Two weeks before seeds were planted, moss was removed from the flats in which it was being cultivated and placed into treatment flats. A flat that received moss was covered 
$100 \%$ with a dense mat $\sim 2 \mathrm{~cm}$ thick for each moss species. The seeds were then sprinkled onto the flats from above in order to simulate aerial dispersal in the swamp. The large size of the seeds meant that for these three species the seeds rested on the surface of the moss and did not penetrate into the mat. This is similar to the situation with these seeds in Bonita Swamp (unpubl. data).

Seedlings were counted weekly for a minimum of three months and the maximum number of seedlings obtained was used in the analyses. For Acer 17 days after initial seeding was used as the germinated seedling count for analysis, that is, after 17 days the number of seedlings did not increase. For Fraxinus 49 days after seeding was used, and for Ulmus 49 days after seeding was used. Acer seeds germinated much more rapidly than did seeds of the other species. Seedling survival was $>95 \%$ for all three species and therefore was not assessed in this study. The greenhouse utilized ambient light which was occasionally supplemented with artificial lighting by fluorescent tubes at about 500 lux during the fall and winter. Thus, Acer received 14-15 hours of light per day where as Fraxinus and Ulmus received 11-13 hours. The greenhouse is heated in the winter and fan cooled in the summer. Greenhouse temperatures ranged from approximately $21^{\circ} \mathrm{C}-29^{\circ} \mathrm{C}$ for Acer in July and $18^{\circ} \mathrm{C}-$ $24^{\circ} \mathrm{C}$ for Fraxinus and Ulmus in the fall and spring.

Germination data for each species were square root transformed to improve normality and homoscedasticity. Treatments were compared by two-way ANOVA and the post-hoc Tukey HSD test using SPSS [41]. Recall that for two-way ANOVA with a significant interaction post-hoc tests examine each treatment combination.

\section{Results}

The two-way ANOVA compares the two treatment regimes; however, the graphs show each treatment combination separately for greater visibility of the results (Figure 1). For the three species both treatment regimes and the interaction were highly significant, except for Acer, in which the substrate regime was not significant (Table 1). Overall the significant interactions showed that the effect of a hydrological regime on germination is influenced by substrate type. That is, for the three species under wetter conditions germination is higher on moss than on soil, but under drier conditions germination is higher on the soil.

Tukey's post-hoc results show that germination varied between the three species depending on both hydrology and substrate (Figure 1). Acer germination was the highest on wet moss and moist soil substrates and lowest on dry moss. Fraxinus germination was higher under wet conditions and lowest under dry conditions. Ulmus seeds had higher germination on moist soil substrate and lowest on dry moss and wet soil. Overall Fraxinus germination is most tolerant of wet conditions, followed by Acer and then by Ulmus.

A germinated seed with a radicle that was unable to penetrate the moss mat to reach the soil was not observed for any of these three relatively large seeded species.
TABle 1: Two-way ANOVA and Tukey HSD results for greenhouse germination of three common wetland tree species under three moisture regimes (dry, moist, wet) on three substrates (Hypnum, Thuidium, bare soil).

\begin{tabular}{lccc}
\hline Species & Treatment & $F$ & Sig. \\
\hline \multirow{3}{*}{ Acer $x$ freemanii } & Hydrology & 26.808 & 0.000 \\
& Substrate & 1.473 & 0.237 \\
& Interaction & 11.879 & 0.000 \\
\hline \multirow{3}{*}{ Fraxinus pennsylvanica } & Hydrology & 721.365 & 0.000 \\
& Substrate & 16.124 & 0.000 \\
& Interaction & 22.581 & 0.000 \\
\hline \multirow{3}{*}{ Ulmus americana } & Hydrology & 33.651 & 0.000 \\
& Substrate & 20.030 & 0.000 \\
& Interaction & 23.761 & 0.000 \\
\hline
\end{tabular}

\section{Discussion}

Based on the germination response to hydrology, the three species appear to have different regeneration niches for germination; that is, Fraxinus prefers the highest moisture levels for germination, Acer less moisture and Ulmus less. At each moisture level this effect is mediated by whether the substrate is moss or bare soil as is seen by the significant interactions and the post-hoc results (Table 1, Figure 1).

Fraxinus, under moist conditions, has higher germination on soil than on mosses. The mosses serve to lift the seed away from the soil making the germination site drier and the mosses may also compete for water with the germinating seed. Under wet conditions the saturated soil surface may reduce germination and so germination is slightly higher on the mosses which lift the seeds above the soil surface. Acer shows a similar pattern as Fraxinus but shifted slightly towards a drier moisture regime. Under wet conditions the moss lifts the seed away from the saturated soil and increases germination, whereas under moist and dry conditions the moss substrate is too dry and germination is higher on soil. For Ulmus, under moist conditions the soil substrate is strongly preferred for germination probably for the same reasons as above that the moss creates a drier substrate. The lack of difficulty for the radicles of these species to reach the soil supports the idea that the differences in germination are due to the moisture level at the point where the seed is located either on the surface of the soil or on the surface of the moss. No consistent differences were observed between the two moss species on germination.

Hörnberg et al. [4] observed "smothering" of germinating seeds by bryophytes. This was not observed in our study in which the seeds were perched on the surface of the moss and the radical appeared to have easily penetrated the moss mat. The species used on our study have larger seeds than the seeds of Abies in Hörnberg et al. [4].

Most Acer and Ulmus seeds germinate soon after dispersal and few enter dormancy [30-32]; however, the Fraxinus seeds used in this study may have been dormant at the time of planting [32-34]. Seed dormancy could potentially affect seed germination response to the substrate and moisture conditions in this study, particularly the wettest conditions. 


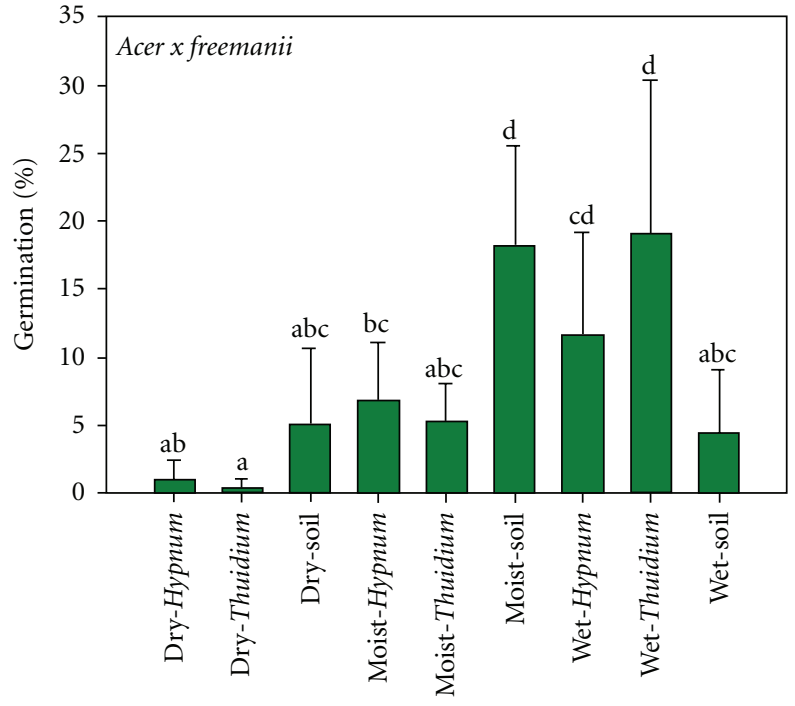

(a)

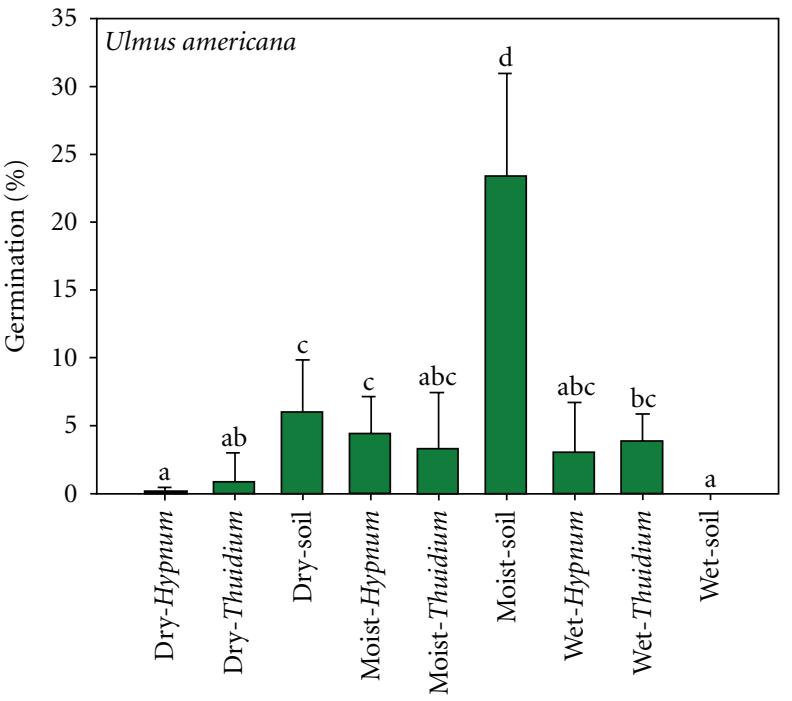

(b)

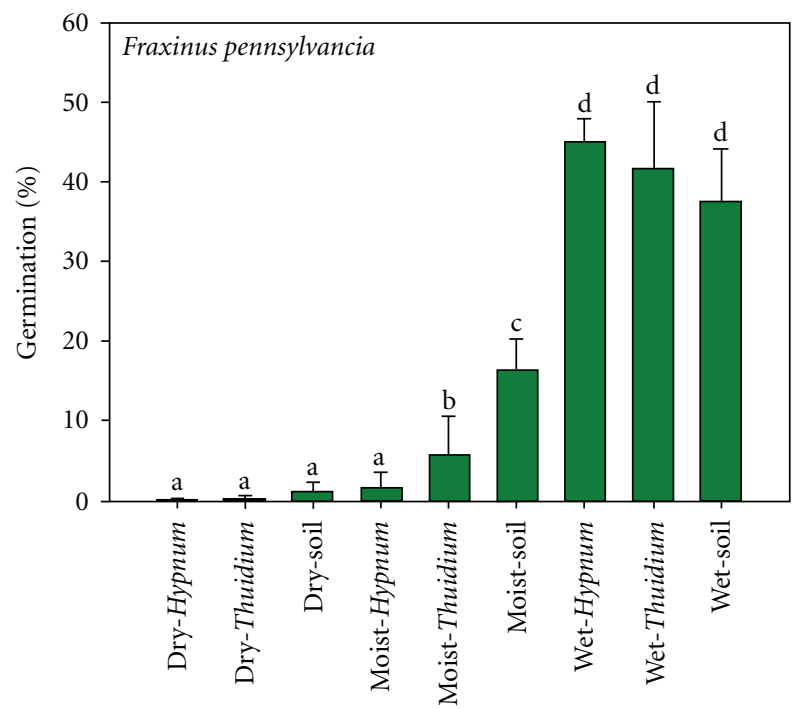

(c)

FIGURE 1: Mean + s.d. \% germination for each of three wetland tree species (Acer $x$ freemanii, Fraxinus pennsylvanica, Ulmus americana) under three hydrological regimes (wet, moist, dry) and three substrates (Hypnum imponens, Thuidium delicatulum, bare soil) in the greenhouse ( $n=8$ for each treatment combination). Seedlings were counted 17 days after seeding for Acer, and 49 days after seeding for Fraxinus and Ulmus. See Table 1 for statistical results. Bars with the same letter are not significantly different by Tukey's post-hoc test at $P \leq 0.5$. Note that the vertical axis scale changes on each graph.

Fraxinus is a very tolerant species and has been observed both germinating in and inhabiting environments from moist to frequently flooded [5]; however, it is possible that dormancy affected the results obtained in this study.

It is possible that the greenhouse conditions influenced germination levels in these species (e.g., [16]). It was cooler (except on sunny days) and days were shorter for Fraxinus and Ulmus than for Acer. It is possible that given longer daylight hours and warmer conditions, for example, the seeds of Fraxinus or Ulmus could be more or less tolerant of wetter conditions. All of the greenhouse temperatures in this study are well within the normal field temperatures at the time of germination for these species, thus, dramatic effects on germination dynamics are unlikely.

Moss cover can have chemical, physical, and mechanical effects on seeds. In this study the major effect appears to be physical with the presence of the moss lifting the germinating seed away from the soil surface decreasing the effective moisture level. These results are similar to those found in other studies where mosses affect moisture levels and thereby influence germination (e.g., [14, 17-19, 22]. Competition for water may also have decreased available water levels. In a swamp, where areas may be inundated for long periods of time, a small change in elevation, such as that provided by 
a moss mat, can have a major effect on moisture levels and therefore germination.

In Bonita Swamp the seeds of these three species are observed in large numbers perched on top of moss mats. By influencing the regeneration niche for the three major tree species of Bonita Swamp and many other swamps in the northeastern United States the bryophyte layer may play an important role in the forest dynamics of these systems.

\section{Acknowledgments}

A Holmberg Research Fellowship to A. Staunch funded this effort. The authors are indebted to E. Fuchs for identifying the mosses. P. Titus assisted in all aspects of the study. This study would not have been possible without the help of L. Blood, L. Martin, C. Sun, J. Wooten, K. Ludwig, and S. Strakosh. E. McCarrick and D. Hunt assisted with logistics. The authors would like to thank J. Jablonski, B. Nystrom, and the Chautauqua Watershed Conservancy for allowing the use of the study site.

\section{References}

[1] P. J. Grubb, "The maintenance of species-richness in plant communities: the importance of the regeneration niche," Biological Reviews, vol. 52, pp. 107-145, 1977.

[2] M. Fenner and K. Thompson, The Ecology of Seeds, Cambridge University Press, Cambridge, UK, 2005.

[3] T. W. Donath and R. L. Eckstein, "Effects of bryophytes and grass litter on seedling emergence vary by vertical seed position and seed size," Plant Ecology, vol. 207, no. 2, pp. 257$268,2010$.

[4] G. Hörnberg, M. Ohlson, and O. Zackrisson, "Influence of bryophytes and microrelief conditions on Picea abies seed regeneration patterns in boreal old-growth swamp forests," Canadian Journal of Forest Research, vol. 27, no. 7, pp. 10151023, 1997.

[5] L. E. Blood and J. H. Titus, "Microsite effects on forest regeneration in a bottomland swamp in western New York," Journal of the Torrey Botanical Society, vol. 137, no. 1, pp. 88$102,2010$.

[6] J. H. Titus, "Microtopography and woody plant regeneration in a hardwood floodplain swamp in Florida," Bulletin of the Torrey Botanical Club, vol. 117, pp. 429-437, 1990.

[7] G. Rusch and J. M. Fernandez-Palacios, "The influence of spatial heterogeneity on regeneration by seed in a limestone grassland," Journal of Vegetation Science, vol. 6, no. 3, pp. 417426, 1995.

[8] L. S. Santiago, "Use of coarse woody debris by the plant community of a Hawaiian montane cloud forest," Biotropica, vol. 32, no. 4, pp. 633-641, 2000.

[9] E. G. Sedia and J. G. Ehrenfeld, "Lichens and mosses promote alternate stable plant communities in the New Jersey Pinelands," Oikos, vol. 100, no. 3, pp. 447-458, 2003.

[10] P. J. Keizer, B. F. van Tooren, and H. J. During, "Effects of bryophytes on seedling emergence and establishment of shortlived forbs in chalk grassland," Journal of Ecology, vol. 73, no. 2, pp. 493-504, 1985.

[11] B. F. van Tooren, "Effects of a bryophyte layer on the emergence of seedlings of chalk grassland species," Acta Oecologica, vol. 11, no. 2, pp. 155-163, 1990.
[12] I. Špačková, I. Kotorová, and J. Lepš, "Sensitivity of seedling recruitment to moss, litter and dominant removal in an oligotrophic wet meadow," Folia Geobotanica, vol. 33, no. 1, pp. 17-30, 1998.

[13] I. Kotorová and J. Lep̌s, "Comparative ecology of seedling recruitment in an oligotrophic wet meadow," Journal of Vegetation Science, vol. 10, no. 2, pp. 175-186, 1999.

[14] M. Zamfir, "Effects of bryophytes and lichens on seedling emergence of alvar plants: evidence from greenhouse experiments," Oikos, vol. 88, no. 3, pp. 603-611, 2000.

[15] M. Jeschke and K. Kiehl, "Effects of a dense moss layer on germination and establishment of vascular plants in newly created calcareous grasslands," Flora, vol. 203, no. 7, pp. 557$566,2008$.

[16] N. A. Soudzilovskaia, B. J. Graae, J. C. Douma et al., "How do bryophytes govern generative recruitment of vascular plants?" New Phytologist, vol. 190, no. 4, pp. 1019-1031, 2011.

[17] B. F. van Tooren, "The fate of seeds after dispersal in chalk grassland: the role of the bryophyte layer," Oikos, vol. 53, no. 1, pp. 41-48, 1988.

[18] H. J. During and B. F. van Tooren, "Bryophyte interactions with other plants," Botanical Journal of the Linnean Society, vol. 104, pp. 79-98, 1990.

[19] T. Nakamura, "Effect of bryophytes on survival of conifer seedlings in subalpine forests of central Japan," Ecological Research, vol. 7, no. 2, pp. 155-162, 1992.

[20] M. Ohlson and O. Zackrisson, "Tree establishment and microhabitat relationships in north Swedish peatlands," Canadian Journal of Forest Research, vol. 22, no. 12, pp. 1869-1877, 1992.

[21] I. Steijlen, M. C. Nilsson, and O. Zackrisson, "Seed regeneration of Scots pine in boreal forest stands dominated by lichen and feather moss," Canadian Journal of Forest Research, vol. 25, no. 5, pp. 713-723, 1995.

[22] J. W. Morgan, "Bryophyte mats inhibit germination of nonnative species in burnt temperate native grassland remnants," Biological Invasions, vol. 8, no. 2, pp. 159-168, 2006.

[23] J. Czarnecka, "Seed longevity and recruitment of seedlings in xerothermic grassland," Polish Journal of Ecology, vol. 52, no. 4, pp. 505-521, 2004.

[24] C. D. Johnson and A. G. Thomas, "Recruitment and survival of seedlings of a perennial Hieracium species in a patchy environment," Canadian Journal of Botany, vol. 56, pp. 572580, 1978.

[25] Y. Kameyama, N. Nakagoshi, and K. Nehira, "Safe site for seedlings of Rhododendron metternichii var. hondoense," Plant Species Biology, vol. 14, no. 3, pp. 237-242, 1999.

[26] H. E. Kirkpatrick, J. W. S. Barnes, and B. A. Ossowski, "Moss interference could explain the microdistributions of two species of monkey-flowers (Mimulus, Scrophulariaceae)," Northwest Science, vol. 80, no. 1, pp. 1-8, 2006.

[27] M. E. Harmon and J. F. Franklin, "Tree seedlings on logs in Picea-Tsuga forests of Oregon and Washington," Ecology, vol. 70, no. 1, pp. 48-59, 1989.

[28] G. Overbeck, K. Kiehl, and C. Abs, "Seedling recruitment of Succisella inflexa in fen meadows: Importance of seed and microsite availability," Applied Vegetation Science, vol. 6, no. 1, pp. 97-104, 2003.

[29] R. L. Eckstein, J. Danihelka, N. Hölzel, and A. Otte, "The effects of management and environmental variation on population stage structure in three river-corridor violets," Acta Oecologica, vol. 25, no. 1-2, pp. 83-91, 2004.

[30] O. M. Freeman, "A red maple, silver maple hybrid," Journal of Heredity, vol. 32, no. 1, pp. 11-14, 1941. 
[31] M. Coladonato, Ulmus americana. In: Fire Effects Information System, U.S. Department of Agriculture, Forest Service, Rocky Mountain Research Station, Fire Sciences Laboratory,1992, http://www.fs.fed.us/database/feis/.

[32] M. A. Dirr, Manual of Woody Landscape Plants: Their Identification, Ornamental Characteristics, Culture, Propagation, and Uses, Stipes Publishing, Champaign, Ill, USA, 1998.

[33] G. P. Steinbauer, "Dormancy and germination of Fraxinus seeds," Plant Physiology, vol. 12, pp. 813-824, 1937.

[34] R. W. Tinus, "Effects of dewinging, soaking, stratification, and growth regulators on germination of green ash seed," Canadian Journal of Forest Research, vol. 12, pp. 931-935, 1982.

[35] L. A. Hyatt and B. B. Casper, "Seed bank formation during early secondary succession in a temperate deciduous forest," Journal of Ecology, vol. 88, no. 3, pp. 516-527, 2000.

[36] J. H. Lambers and J. S. Clark, "The benefits of seed banking for red maple (Acer rubrum): maximizing seedling recruitment," Canadian Journal of Forest Research, vol. 35, no. 4, pp. 806813, 2005.

[37] J. H. R. Lambers, J. S. Clark, and M. Lavine, "Implications of seed banking for recruitment of southern Appalachian woody species," Ecology, vol. 86, no. 1, pp. 85-95, 2005.

[38] L. E. Blood, H. J. Pitoniak, and J. H. Titus, "Seed bank of a bottomland swamp in Western New York," Castanea, vol. 75, no. 1, pp. 19-38, 2010.

[39] A. E. Murray, "Acer x freemanii, E. Murray, Hybrida Nova," Kalmia, vol. 1, pp. 2-3, 1969.

[40] J. Schlegel, "A "new" tree in western New York: the Freeman maple," Clintonia, vol. 21, pp. 1-3, 2006.

[41] SPSS, PASW for Windows Release 18.0.0, SPSS, Chicago, Ill, USA, 2009. 

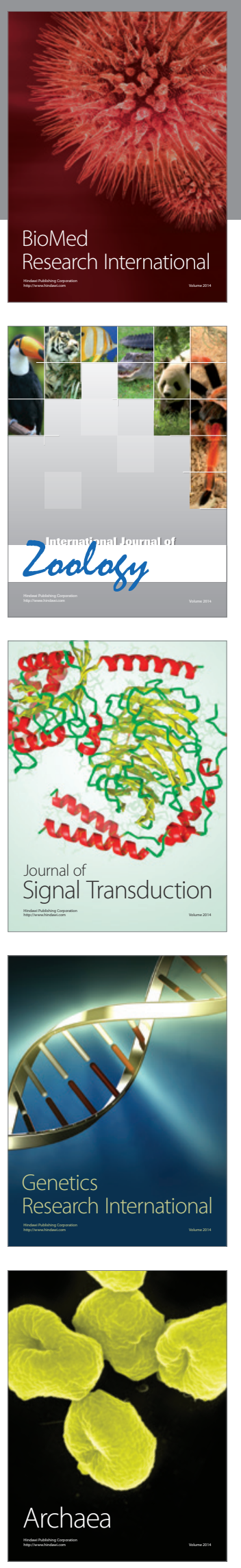
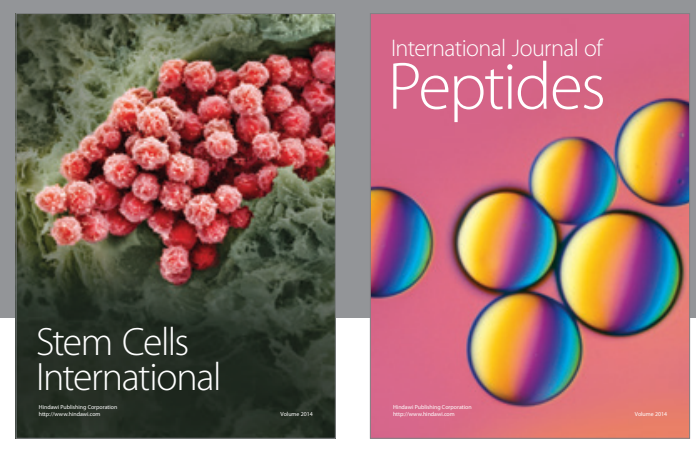

Submit your manuscripts at

http://www.hindawi.com
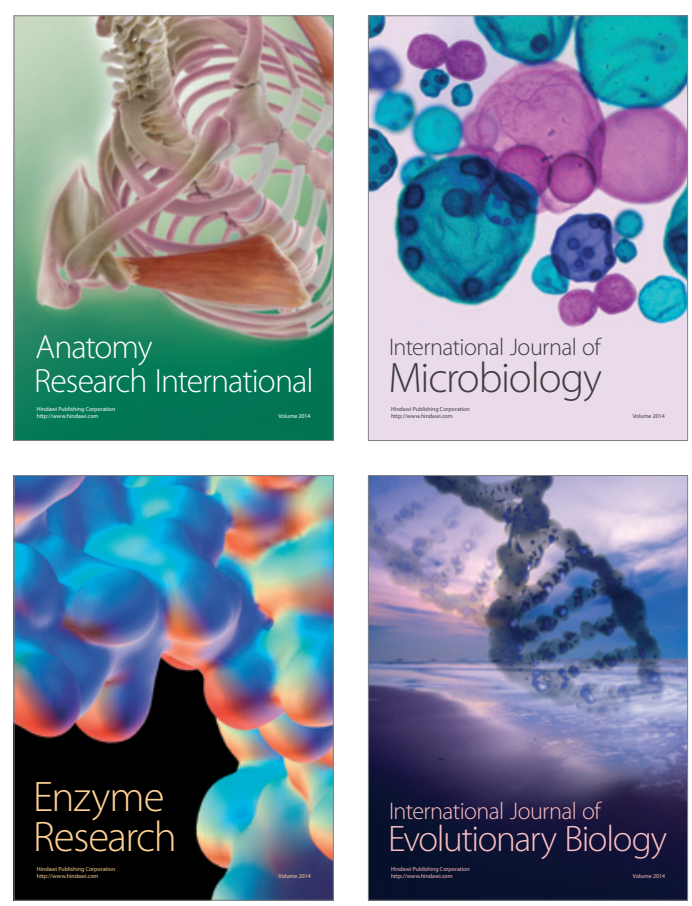
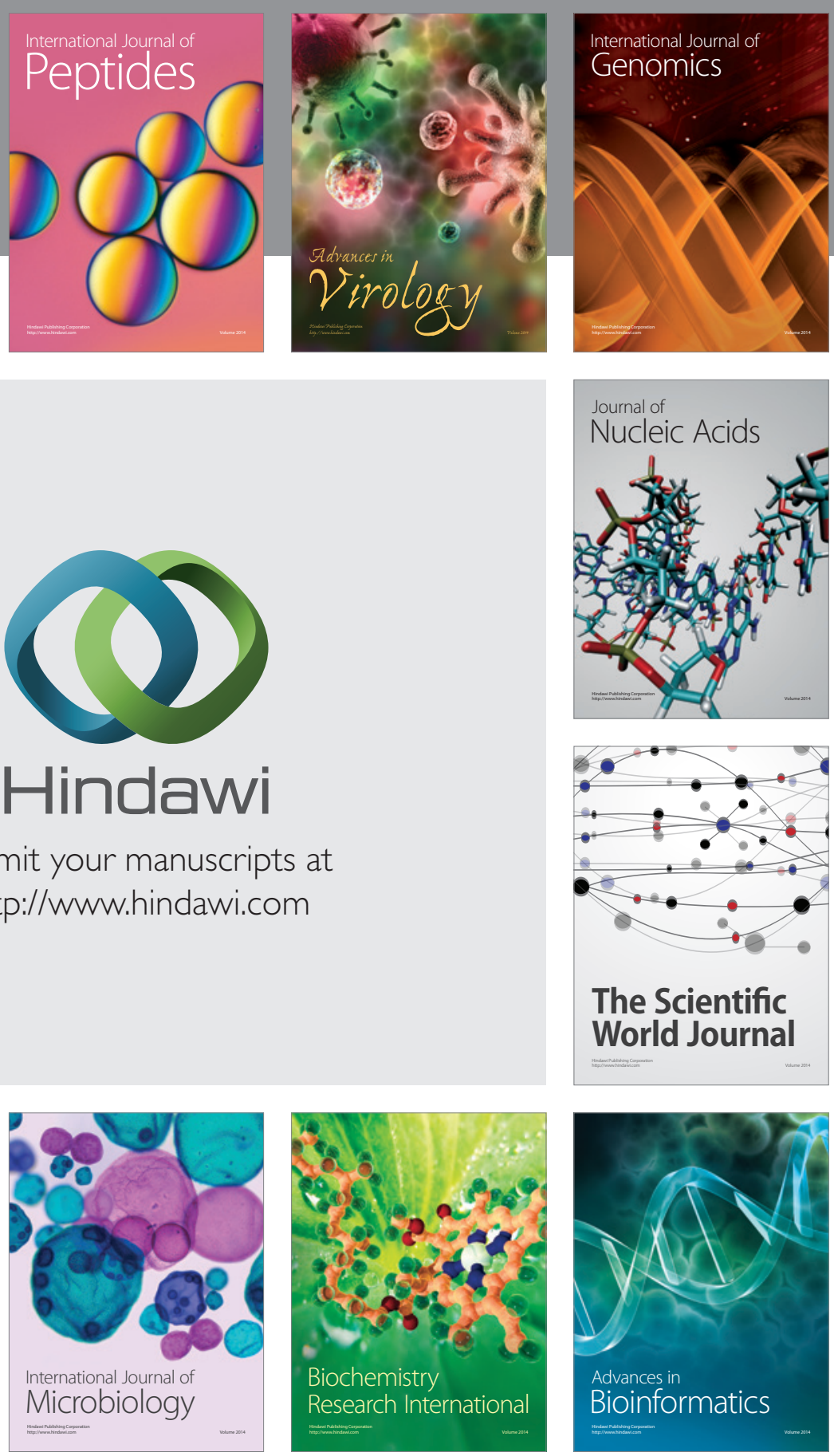

The Scientific World Journal
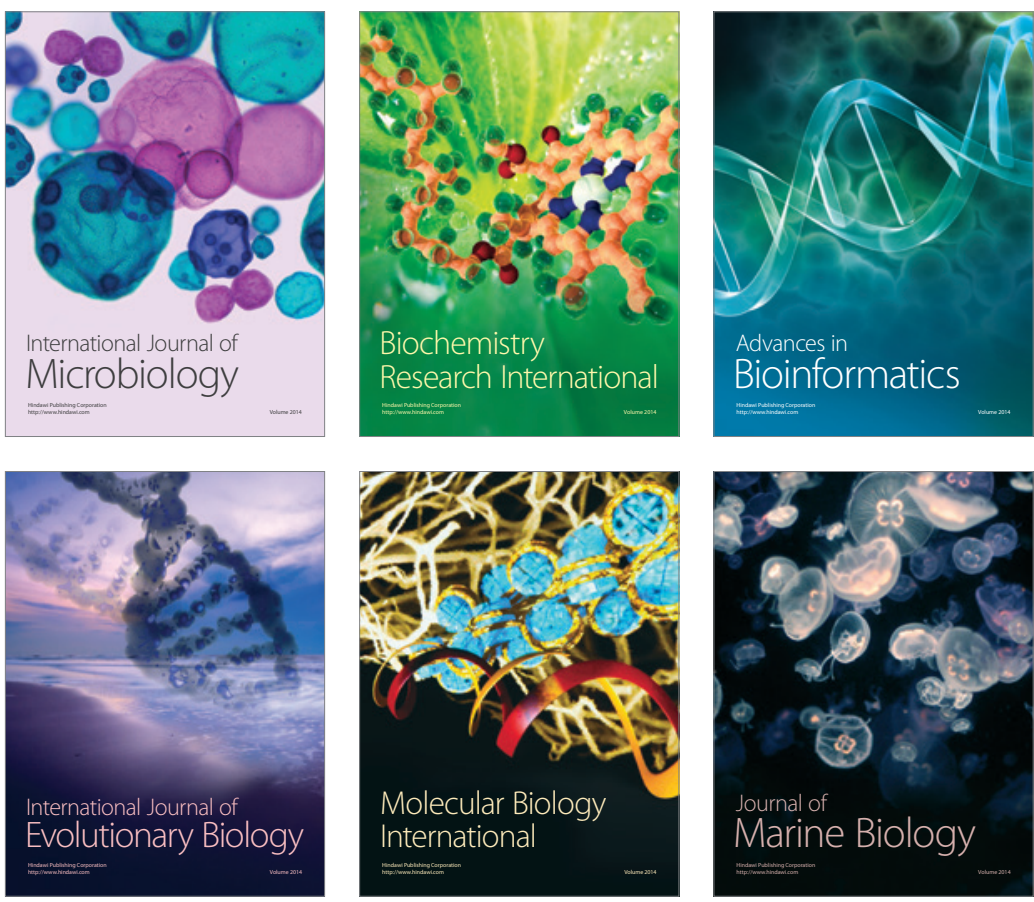